\title{
Rural Malay Involvement in Malaysian Herbal Entrepreneurship
}

\author{
Kamal Chandra Paul ${ }^{1}$, Azimi Hamazah ${ }^{1}$, Bahaman Abu Samah ${ }^{1}$, Ismi Arif Ismail ${ }^{1} \&$ Jeffrey Lawrence D’Silva ${ }^{1}$ \\ ${ }^{1}$ Laboratory for Citizenship and Leadership, Institute for Social Science Studies, Universiti Putra Malaysia, \\ Malaysia \\ Correspondence: Jeffrey Lawrence D'Silva, Laboratory for Citizenship and Leadership, Institute for Social \\ Science Studies, Universiti Putra Malaysia, Malaysia. Tel: 60-3-8947-1862. E-mail: jld@upm.edu.my
}

\author{
Received: September 6, 2013 Accepted: November 14, 2013 Online Published: December 29, 2013 \\ doi:10.5539/ass.v10n2p202 URL: http://dx.doi.org/10.5539/ass.v10n2p202
}

\begin{abstract}
Rural entrepreneurship is recognized as a primary engine of economic growth. The government of Malaysia is trying to increase the number of successful rural Malay herbal entrepreneurs nationwide. Therefore, the purpose of this study was to explore the involvement among rural Malay youth in herbal entrepreneurship in Malaysia. A qualitative approach using case study in-depth interview was used to gather data from ten rural herbal entrepreneurs. This study showed that in general Malay entrepreneurs are increasing gradually but technical based entrepreneurship is very low. It is suggested that the authorities of rural herbal development planners, government-link companies and other authorized agents need to focus on issues related to human capital, technical knowledge know-how and financial resources to increase the involvement of rural Malay youth herbal entrepreneurs.
\end{abstract}

Keywords: rural entrepreneurship, small medium enterprise (SME), qualitative methodology, case study, herbal industry

\section{Introduction}

Globally many countries accept the fact that the field of rural entrepreneurship is a key factor to develop the country's economy growth, quality of life and job creation (Van Praag \& Versloot, 2007; Paul et al., 2013; McMullen, Bagby, \& Palich, 2008; Audretsch, 2007; Shu, 2001; Robinson et al., 2004; Norhaiyati et al., 2011) and this is closely related to small medium enterprises (SMEs). Previously many economists scholar, researchers, academicians believed that the larger firms are the major contributors to a country's economics, job creation and quality of life (Paul et al., 2013). However, lately a new scenario had taken place when countries like China, India, Japan, Korea, Malaysia, Taiwan and Thailand had demonstrated that the booster to their economics are contributed from small medium enterprises. According to Schapper (2006), all developing countries have more than $90 \%$ involvement from the SMEs group and microenterprises category. However, in Malaysia, Hamidon (2009) mentioned that Malay entrepreneurship in successful level is very low relatively to other ethnic groups. As for example in 2006 Malay and Chinese ownership of share capital are RM120,387.6M (19.4\%) and RM263,637.8M (42.4\%) respectively (Hamidon, 2009). The above data showed till now Malay entrepreneurs are in the infancy stage. Therefore, the government of Malaysia is trying to increase the number of successful rural Malay youth herbal entrepreneurs nationwide and provide them with all the necessary support. According to Murray (2011) the herbal entrepreneurship in Malaysia has become another economic growth and it has the potential to become a significant industry. The estimated market value of the herbal industry is RM7.97 billion (Kasim, 2007). Besides this, there are also changes in Malaysian life style whereby there exists a growing emphasis on health and synthetic medicines (Aziz, 2003).

Due to its excellent tropical climate, increase in research and development interest, increase in natural products demand and indigenous knowledge put Malaysia as having a huge potential size in terms of herbal based market (Ibrahim, 2006; Jamai, 2006). However, the Malays involvement in technology related entrepreneurship like health herbal, cosmetics, pharmacy and personal hygiene is very low(Ling et al., 2009). Until today, the Malaysian herbal industry is facing numerous problems like shortage of raw-materials, limited scope of large scale herbal cultivation and shortage of skilled manpower (Hawa, 2011; Viduriati et al., 2012; Nordin et al., 2008). However, there are a lot of opportunities for improvement of new and old products, improved technologies which herbal entrepreneurs could venture into a government authorized good manufacturing practice (GMP) holder entrepreneurs (Ismail \& Sulaiman, 2007; Ellitan, 2002) and existence of government 
authorized agents such as MARDI and FRIM. It is proved that there is a huge potential in current herbal market but successful rural Malays youth herbal entrepreneurship in Malaysia is still very low compared to other ethnic groups in Malaysia. It is evident that until today, very few critical researches have been carried out particularly on the involvement and development of technology-based rural Malay herbal entrepreneurship (Paul et al., 2013; Smith et al., 2009; Ucbasaran et al., 2001; Kirzner, 1973; Baron \& Shane, 2005; Christensen et al., 1994; Hills, 1995; Shane \& Ventakaraman, 2000; Timmons et al., 1987). Hence, this study is designed to identify the level of involvement of rural youth Malay in herbal entrepreneurship in Malaysia.

\subsection{Literature Review}

Entrepreneurship plays an eminent function in creating an avenue for employability for rural communities, providing self-employment for those who have started-up a business of their own and enhancing the economic status of the rural sector as well. Entrepreneurship has transformed their vicinity into trading hubs thus enabling them to become urbanized area. According to the Rural Poverty Report, 2001, 75\% peoples of the world are in the poverty level and more than 1.3 billion peoples in this world live in extremely poverty such as one in every five person. In rural about 900 million peoples of the world are lived in the rural area and they are depend on agriculture and other related activities for their livelihoods.

Entrepreneurship is a vital component of productivity and growth (Baumol, 1993). Previous study showed that a strong positive relation between the level of economic activity and overall economic performance (Zacharakis et al., 1999) Therefore, at present global world the entrepreneurs play a number of critical roles in economic development (Schumpeter, 1934) of developing countries.

Rural entrepreneurship occurs in economically and socially depressed areas with inadequate infrastructure, economic stagnation, low level of education, unskilled workers, limited income and a culture not supportive of entrepreneurship (Kulawczuk, 1998). Fostering entrepreneurship is a crucial factor in energizing the rural economy (Petrin \& Gannon, 1997) in impoverished rural regions because entrepreneurship creates wealth and employment and the quality of life of rural populations (FAO Corporate Document Repository, 1997).

The literature review indicates that until today, opportunity recognition in rural entrepreneurship has not received a great deal of attention in entrepreneurship related research. Therefore, it seems useful and timely to do further study opportunity recognition in rural entrepreneurship.

\subsubsection{Education and Knowledge and Training}

Intellectual and human capital in entrepreneurship involved the knowledge and education and training of the entrepreneurs. The low education of rural entrepreneurs is one of the main contributors to the growing rate of economic between urban and rural regions. Education always increases the quality of human capital and it is very essential for rural entrepreneurial communities to develop their entrepreneurship (Florida, 2002). Rural development depends on skilled peoples and human capital knowledge which is also important for rural entrepreneurs for developed their entrepreneurship (Malecki, 1999; Petrin \& Gannon, 1997).

Training programs that involve rural entrepreneurship development can be agriculture or other fields. Training in agriculture sectors may target the application of suitable technologies and methods (Lohmoller, 1990). Training farmers on various strategies and agriculture techniques promotes to recognize opportunities in rural regions (Lohmoller, 1990). Training on others field will also teach rural communities various ways to diversify and develop other business sector (Petrin, 1997).

\subsubsection{Social Network}

According to social network theory, social ties influence their recognition of entrepreneurial opportunities and entrepreneurial pursuits (Hills et al., 1999). The development of rural entrepreneurship is necessities through social network (Dabson, 2005). Developing partnership includes the coordinated efforts of central government, local governments, municipalities, academies and non-governmental organizations to help spur the entrepreneurial activity of that region (Kulawczuk, 1998).

\subsubsection{Availability of Financial Resources}

The availability of financial resources for new firms and the strength of infrastructures were found to be highly correlated with the level entrepreneurial activity across countries (Zacharakis et al., 1999). Promoting rural entrepreneurship requires financial resources such as funds for loans, investments and technical assistance for micro enterprises (Kulawczuk, 1998). In this study, the availability of financial resources specifically refers to low interest government loans, credit counseling and technical assistance to rural entrepreneurs. Financial support may play a role in observing opportunities and creating motivation for individuals to exploit 
opportunities (Zackharakis et al., 1999). Therefore, it is assume that increasing funds for rural regions enables rural communities to start their entrepreneurship. The greater the extent to which rural entrepreneurs have access to business financing.

\section{Methodology}

This is a qualitative case study approach, using in-depth interview among ten rural Malay youth herbal entrepreneurs from five states of Malaysia namely Kelantan, Kedah, Pahang, Trangganu and Selangor. Case study is useful research methodology for rural entrepreneurship development (Barkley, 2006). This study research is a comprehensive research strategy that includes the development of theoretical model, research design, data collection and analysis. For entrepreneurship qualitative research, it is preferred to use multiple-case design compared to single. As stated by Henderson (2001), case study multiple-approach is very popular for rural entrepreneurship development. Besides, qualitative research would ensure that the analysis relied on all evidence and it is most significant for the case study (Yin, 1994). It also provided rich and thick description from the informant's experiences and perception on the backwardness of rural herbal entrepreneurs.

\subsection{Sample Selection}

The primary goal of this research was to investigate the involvement of rural Malay youth Malaysian herbal entrepreneurship. For this study, the researcher had selected ten rural Malay youth herbal entrepreneurs from five states. These herbal youth entrepreneurs are running this entrepreneurship after completing their basic education in their rural areas.

\subsection{Data Collection}

Data were gathered from semi-structured in-depth individual face to face interviews and observation. For semi-structured interviews, an interview protocol was formed. The average interview time for each participant was an hour to one and a half hour. It was recommended by Yin (1994), the open-ended interviews were used to expand the depth of data gathering and to increase the number of source information. The need for triangulation arises from the ethical need to confirm the validity of the process. The information gathered was written down in a log book with the summary from the interviews. The main purpose of these observations was primarily to verify the information collected from interviews.

\subsection{Data Analysis}

For analysis of interview data was started with the coding process. The whole transcribed interviews were read in order to locate the relevant segments that corresponded with previous identified categories and to code them. Then the relevant segments of data with their respective coding inserted in brackets were retyped and made bold. Now, the difference and similarities between codes were properly checked and these codes were categorized as their similarities. In the next step, analysis was carried out looked how this coded concepts helped to get the answers of the questions posed. The details of the respondent information are as follows.

\section{Respondent 1 (R1): Anowar Bin Mustafa, Entrepreneurship Name "A"}

Encik Anowar is 27 years old, owner of the entrepreneurship "A" which was established in Kelantan in 1983. All his ten products are sold through government promotional support, social network, internet marketing and authorized agents and total monthly sales about RM90K. He told "We are doing technical-based entrepreneurship since the beginning but to follow the government current rules and regulation, government should provide the following full support:

\section{1) Financial}

2) Training monitoring system

3) To develop a 'Separate unit for Rural herbal entrepreneurs those are fully involved in manufacturing by the Ministry of Health' (Currently it is under associated with few ministries)

There are five brothers in my family but only myself involved in this family business, they are working in different companies because very difficult to run this, we are always short of fund in the bank and our profit margin is not enough. Rural entrepreneurs buy all the productions materials at higher prices, no one want to give us credit facilities. As a result our business growth all the time is same. The government should take special care of us. As a young person, I love this technical business but sorry to say every year rural herbal entrepreneurs change to general entrepreneurship like Kedai Runcit (glossary shop).

Respondent 2 (R2): Cik Noorul Ainur Mohd Zulkarin, Entrepreneurship Name "B"

The entrepreneur age is 37 and she started her business in 2002 in her village, the state of Kelantan. After 
completing her basic education she worked as a sales girl in a rural herbal medium size company with a monthly salary of RM800.00 for five years. She started herbal business with a capital of RM30K from her savings near her home town in Kelantan. She bought all the raw materials from the local market and produced it in her small location. For financial problem she can't develop the product like other established entrepreneurs. That's why only rural community people buy her product. She mentioned that she failed to get any business loan since the loan from the government authorized bank or agent is very strict. She needs strong financial, human capital and technical knowledge know-how training immediately. If she managed to get all support from the government then she will develop her entrepreneurship. Otherwise she has to shut down her business because she is unable to solve her critical problem.

Respondent 3 (R3): Abu Baker Bin Sulaiman, Entrepreneurship Name "C"

$\mathrm{He}$ is one of the successful rural herbal entrepreneurs in Kedah, West Malaysia. Mr Abu was born in Alor Star, Kedah in 1980 and he is running his family business after graduating in business studies last year. As a business graduate young entrepreneur he changed all this traditional business policy and now got business not only locally, also internationally after getting a business loan from the government commercial bank. He has now five herbal products in the market and monthly sales about more than RM200K. He told in his interview that until today the government is not getting real information from the researchers on the reasons of unsuccessful rural Malay herbal entrepreneurs. We are always waiting for government loan or other support without business plan. If can't get any support then simply blame government. Sometimes, managed to get loan for business purpose but at the end misused the fund. That's why we are until today so lagging in entrepreneurship relatively to other ethnic groups in Malaysia. He also told we need government immediate monitoring activities mainly in rural Malay youth herbal entrepreneurs. Finally, try to stop third party involvement as an agent as long as government can handle it.

\section{Respondents 4 (R4): Shahrizat Mohd Hossain, Entrepreneurship Name "D"}

In the year 1996, Cik Shahrizat established her entrepreneurship business in Kedah after her husband died from liver cancer. She always thinks technical business that can make good money. I learn basic herbal knowledge from India and herbal or traditional related journal or magazine. Currently, her monthly sale is about RM 75K and she can't develop her business due to finance. We have business but need support from government urgently. Our product is not of international standard and until today we can't develop the technical part, and human capital knowledge. She told "we are not helping each other to develop our business at all. But Chinese, they are all well organized and always help each other. They have the entrepreneurial attitude that's why they are market leader in products. May be one day we can be successful herbal entrepreneurs.

Respondents 5 (R5): Azman Wan Yusop, Entrepreneurship Name "E"

Mr Azman was born in Pahang and he holds his computer engineering in 2000 and while being a government officer in Malaysia he started his herbal entrepreneurship from his innovated herbal product located in Tremoloh, Pahang. Due to government lack of financial support until today he finds it difficult to achieve the developing stage on the herbal production. The monthly sales are very less for his low quality product relatively to other rural herbal entrepreneurs among his community. This respondent told that for lack of financial, technical knowledge and human capital, young herbal entrepreneurs are buying from contract herbal manufacturer or Mardi product used their own brandas their capital. It is like trading just selling one product in a different name as nascent entrepreneur choice. So at the end, all the rural herbal entrepreneurs either change to sale contract herbal manufacturer products or stop it and look for job.

\section{Respondents 6 (R6): Zulkifleeuthman, Entrepreneurship Name "F"}

The entrepreneur's age now is 38 and set up his entrepreneurship in 1998 with five products. All his family members are involved in his family business. His father has innovated herbal product since long but till now is in the infancy stage. For low quality products, other ethnic groups are not interested to buy his products. Only he is surviving from his own community people sales. We are not in aposition to follow the government new current guidelines unless they provide us all the facilities. Better stop our generation entrepreneurship to become nascent herbal entrepreneurs. For us no headache for operation and manufacturing cost, just buy and sell or stop this entrepreneurship and look for new job.

\section{Respondents 7 (R7): Amir Hussain Md Jalil, Entrepreneurship Name "G"}

Mr Amir has completed his basic education in Rawang, Kualalumpur. His herbal enterprise was established in 1997 at Batang Berjuntai, Selangor run by all his family members. He took over it just after his father passed away in 2003. They have their own sales agent in few states but sales are too poor because of unskilled sales 
team. At present the monthly sales are between RM35K to RM40K and that is the reason they are trying hard to get the government or other finance organization loan for their business plan. If not then they will completely shut down their generation entrepreneurship and will start to sell the contract herbal manufacturer product as our name just like nascent entrepreneurs.

\section{Respondent 8(R8): Syed Hussain Bin Hashem, Entrepreneurship "H"}

This rural herbal entrepreneurship was run by a young couple 39 (both same age) since they are married in 1996. They are both good in computer knowledge, office management and marketing skill. At present, their monthly sales are about RM78K to RM80K. Both are from Machang, Kelantan but permanently settled down in Selangor. Now they have five employees. They have sales agent from different ethnic groups such as Chinese, Indians and others. That's why they are doing very well and always trying to full-fill the market demand. The couple told that they have good business but for limited capital they find difficulties to delivery the products on time and employees salary. Bank and other finance company do not accept their finance company then we buy new machine for our production increase and also can follow health ministry new guidelines for herbal entrepreneurs. They are both very dynamic and entrepreneurial attitude is very strong. But they said "At present, in supermarket, drug store, we cannot sell our products for low quality products. But in ten years time rural youth herbal entrepreneurs may be change the consumer perception because that time young generation will start this type of technical-base entrepreneurs after getting basic education and sufficient bank loan. Now, most of the rural youth entrepreneurs are lagging behind due to capital, technical knowledge and human capital.

Respondent 9(R9): Ahmad Raflis Che Omar, Entrepreneurship Name "I"

His home town is in Muar, Johor. It's their grandfather generation entrepreneurship, started in 1970. After completing his bachelor degree in agriculture from Universiti Putra Malaysia (UPM) in 2001 he joined this herbal entrepreneurship with a new development plan. From 2008 the business growth was tremendous and monthly sales increased from RM79K to RM100K. However, with the current government policy on herbal entrepreneurship everyone has to follow the new guidelines if want to develop locally or internationally. Otherwise no one can sell their products in the market. Mr Ahamad failed to get government support, bank loan to develop the manufacturing area. Therefore, his sales now reduced to between RM40K to RM50K. At present, he is selling Mardi commercialization products under his enterprise name. He told "all of his family members are now working some and closed his 40 years old family business due to financial and other related problems.

\section{Respondent 10(R10): Mr Ridwan Bin Mohd Napi, Entrepreneurship Name "J"}

Mr Ridwan was born in Pasir Gudang, 1980. His parents stayed in Malaysia since 1972 after his father joined as a religious teacher in Johor. The herbal business started in 2002 with the help of his Chinese business friend. He has five sales agents such as Johor, Melaka, Pahang, Kelantan and Perlis and monthly sales are now around RM70K. For their low grade products finding so difficult to enter in different super markets, drugs store and other stationery shops. In the meantime, the government forces us to change the traditional production method which is big money investment, not possible to develop our whole structure immediately unless get support either from government or financial bank. Mr Ridwan told "I love this technical herbal entrepreneurship since I started it but now we need at least RM100K urgent to change new technology as government needed. We do not have that much of amount in our hand or any friends, or relatives to help us. Finally, I decided to do sell contract herbal manufacturers products under our entrepreneur's name without any headache.

\section{Discussions, Findings and Recommendations}

Based on the ten respondent's data, five common factors were identified on the involvement of rural Malay youth in herbal entrepreneurship, (1) Attitude and mindsets, (2) Lack of competitiveness of sustainability, (3) Lack of entrepreneurial culture, (4) Lack of cooperation each other and networking, (5) Government support and new drug policy on herbal entrepreneurs. In the conclusion, the study integrated the reason to reduce rural herbal entrepreneurs and join as a nascent small medium enterprise groups.

The findings identified that the government has made initiative plans to increase the number of rural Malay herbal entrepreneurs and development of their entrepreneurship but majority were unsuccessful until today. From the findings of this research, it is understood that major causes are inadequate financial support and government new herbal policy. In addition, it was also identified that if rural Malay youth entrepreneurs do not change their psychological behavior as entrepreneurs, they will be lagging behind day by day with their business. On the other hand, the government needs to modify certain rules to help to increase the number of rural herbal youth entrepreneur. If these plans were to be taken then rural herbal entrepreneurship will be developed rapidly.

In order for Malay entrepreneurs to be successful in their business they should cultivate positive characteristic as 
explained by success factors in order, namely advancement drive, achievement target, commitment, decision-making capacity, ability to handle risk, tenacity, network and optimism.

In addition, government and other relevant parties should recognize the importance of the above factors that can play an important role in developing these positive characteristics among rural Malay youth herbal entrepreneurs There is a need to build strong confidence and change the previous expectation and cultural mindset in becoming more entrepreneurs. And also it would be a collective action from government and people.

The positive characteristics of successful entrepreneur attention should be given to develop the, marketing -related program, seminars and conferences, network development that linkages with government social groups and agencies. Finally, government policy makers should overcome a misconception suffered by government agencies which are mostly bureaucratic.

\section{References}

Abdul, A. R. (2003). Turning Malaysia into a global herbal producer: A personal perspective. Siri Syarahan Perdana Professor, University Technology Malaysia.

Audretsch, D. B. (2007). Entrepreneurship capital and economic growth. Oxford Rev.

Barkley, D. L. (2006, October 26-27). Presented at the joint ERS-RUPRI conference, Exploring Rural Entrepreneurship: Imperatives and opportunities for Research. Washington, DC.

Baron, R., \& Shane, S. (2005). Entrepreneurship: A process perspective. South-Western, Mason, OH.

Baumol, W. (1993). Entrepreneurship, Management and the structure of payoffs. The MIT Presss. Cambridge: Massachusetts.

Christensen, P. S., Madsen, O. O., \& Peterson, R. (1994). Conceptualising entrepreneurial opportunity recognition. In G. E. Hills (Ed.), Marketing and entrepreneurship: Research ideas and opportunities. Quorum books Westport, CT (pp. 61-75). Econ. Policy, 23, 63-78.

Dabson, B. (2005). The Big Picture Context for Rural Entrepreneurship. Iowa Community Entrepreneurship Academy in Manning, Iowa.

Ellitan, L. (2002). Factors influencing the success of technology adoption: A case study of Indonesian manufacturing firms. Master's Thesis, Universitas Kristen Petra, Surabaya, Indonesia.

Florida, R. (2002). The Rise of the Creative Class: And how it's Transforming Work, Leisure, Community and Everyday life. Perseus Books Groups.

Food and Agriculture Organization of the United Nations (FAO) Documents. (1997). Retrieved from http://www.fao.org/documents/show_cdr.asp?url_file=/DOCREP/W6882e/W6882e/W6882e.htm

Hamidon, S. (2009). Development of Malay Entrepreneurship in Malaysia. PhD thesis, Massey University, Auckland, New Zealand.

Hawa, Z. J. (2011). Growing Our Herbal Industry. Retrieved from http://pmr.penernagan.gov.my/index.php/sosial/11684

Henderson, J. R. (2001). Networking with E-commerce in Rural America. The Main Street Economist, Federal Reserve Bank of Kansas City, Center for the Study of Rural America, September.

Hills, G. E., Shrader, R. C., \& Lumpkin, G. T. (1999). Opportunity recognition as a creative process. Frontiers of Entrepreneurship Research, 216-227. Wellesley, MA: Babson College.

Ibrahim, J. (2006). The Scientific values of Malaysians herbal Products. Malaysian Journal of Health Science, $4(1), 59-70$.

IFAD. (2001). International Fund for agriculture Development, Rural Poverty Report: The challenge of ending poverty. Retrieved from http://www.ifad.org/poverty/chapter2.pdf

Ismail, R., \& Sulaiman, N. (2007). Technical efficiency in Malay manufacturing firms. International Journal Business Society, 8(2), 24-37.

Jamai, A. J. (2006). Malay traditional medicine: An overview of scientific and technological progress. Asia-Pacific Tech Monitor.

Kirzner, I. M. (1973). Competition and entrepreneurship. University of Chicago Press, Chicago.

Kulawczuk, P. (1998). The development of entrepreneurship in rural areas (Chapter 5, pp. 97-109). In J. D. Kimball (Ed.), The Transfer of Power: Decentralization in central and Eastern Europe. The Local Government and Service FromInitiative. Budapest: Hungary.

Lohmoller, G. (1990). Concept for the development of entrepreneurial activities in the rural area for farmers and managers of small and medium sized enterprises. Paper presented at the Fifth Session of the FAO/ECA Working party on Women and the Agricultural Family in Rural Development, Prague, Czechoslovakia, 2-5 October.

Malecki, E. J. (1997). Technology and Economic Development: The Dynamic of Local, Regional and National 
Competitiveness. Longman, Essex, England.

McMullen, J. S., Bagby, D. R., \& Palich, L. E. (2008). Economic freedom and the motivation to engage in entrepreneurial action. Entrepreneurship Theory and Practice, 32, 875-895. http://dx.doi.org/10.1111/j.1540-6520.2008.00260.x

Murray, H. (2011). Expanding the Malaysia herbal industry by developing the farmer-government University Nexus. Processing of the $7^{\text {th }}$ Malaysian Agro-Bio International Conference with the $12^{\text {th }}$ Malaysian International Food and Beverage Trade Fair, July 12-15, 2011, Putra World Trade Centre, Kualalumpur, Malaysia.

Nordin, N., Othman, S. N., \& Mat, R. C. (2008). Technology implementation barriers in the Malaysian herbal industry: A Case Study. Malaysian Management Journal, 12(1\&2), 79-88.

Norhaiyati, A. M., Nik, M. N., \& Md, W. Z. W. M. (2011). The influential factors in decision-making process among Malay Women Entrepreneurs. The Institute for the Empowerment of Women Malaysia, Kualalumpur.

Paul, K. C., Hamzah, A., AbuSamah, B., Ismail, A. I., \& D’Silva, L. J. (2013). Development of Rural Herbal Entrepreneurship in Malaysia. International Journal of Business Management, 8(18). http://dx.doi.org/10.5539/ijbm.v8n18p95

Petrin, T. (1997). Entrepreneurial development process: A training approach. In Food and Agriculture Organization of the United Nations (FAO) Document Repository. REU Technical Series 41. Retrieved from http://www.fao.org/documents/show_cdr.asp?url_file=/DOCREP/W6882e.htm

Petrin, T., \& Gannon, A. (1997). Rural development through entrepreneurship. FAO, Rome (Italy). Regional Office for $\quad$ Europe. $\quad$ Retrieved from http://www.fao.org/documents/show_cdr.asp?url_file=/DOCREP/W6882e/W6882e00.htm

Robinson, K. L., Dassie, W., \& Christy, R. D. (2004). Entrepreneurship and Small Business Development as a Rural Development Strategy. Southern Rural Sociology, 20(2), 1-23. Copyrights (2004) by the Southern Rural Sociological Association.

Schaper, M. T. (2006). Distribution pattern of small firms in developed economies: Is there an emergent global pattern? International Journal of Entrepreneurship and Small Business, 3(2), 183-189. http://dx.doi.org/10.1504/IJESB.2006.008927

Schumpeter, J. A. (1934). The Theory of Economic Development. Cambridge: Harvard University Press. (New York: Oxford University Press, 1961). First Published in German, 1912.

Shane, S., \& Ventakaraman, S. (2000). The promise of entrepreneurship as a field of Research. Academy of Management Review, 25(1), 217-226.

Shu, X. (2001). Entrepreneurship and economic growth. Proceeings of the Sino-Australian Conference of Innovation and Entrepreneurship, Policy and Practice, November 7-9, 2001, Hangzhou, China.

Smith, B. R., Matthews, C. H., \& Schenkel, M. T. (2009). Differences in entrepreneurial opportunities: The role of tacitness and codification in opportunity identification. Journal of small business management, 47(1), 38-57. http://dx.doi.org/10.1111/j.1540-627X.2008.00261.x

Timmons, J. A., Muzyka, D. F., Stevenson, H. H., \& Bygrave, W. D. (1987). Opportunity recognition: The core of entrepreneurship. In N. C. Churchill et al. (Eds.), Frontiers of Entrepreneurship Research. Babson College Wellesley, MA.

Ucbasaran, D., Westhead, P., \& Wright, M. (2001). The focus of entrepreneurial research: Contextual and process issues. Entrepreneurship: Theory and Practice, 25(4), 57-80.

Van Praag, C., \& Versloot, P. (2007). What is the value of entrepreneurship? A review of recent research. Small Business Econ., 29, 351-388. http://dx.doi.org/10.1007/s11187-007-9074-x

Viduriati, S., Golnaz, R., Zainal, A., Mad, N. S., \& Juwaidah, S. (2012). The motivational and social factors in predicting the intention of herbal-based entrepreneurs towards going green. UMT $11^{\text {th }}$ International Annual Symposium on Sustainability Science and Management $9^{\text {th }}$ to 11 July 2012, University Malaysia Terengganu, Malaysia.

Yin, R. (1994). Case study research: Design and methods. Beverly Hills, CA: Sage Publishing.

Zacharakis, A., Reynolds, P. D., \& Bygrave, W. D. (1999). Global Entrepreneurship Monitor: National Entrepreneurship Assessment: United States of America Executive Report.

\section{Copyrights}

Copyright for this article is retained by the author(s), with first publication rights granted to the journal.

This is an open-access article distributed under the terms and conditions of the Creative Commons Attribution license (http://creativecommons.org/licenses/by/3.0/). 